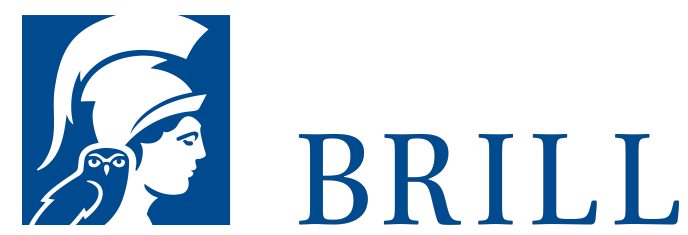

\title{
Circum Mare: Themes in Ancient Warfare
}

\section{Editor: Jeremy Armstrong}

Circum Mare: Themes in Ancient Warfare presents a thematic approach to current directions in ancient military studies with case studies on topics including the economics of warfare, military cohesion, military authority, irregular warfare, and sieges. Bringing together research on cultures from across the Mediterranean world, ranging from Pharaonic Egypt to Late Antique Europe and from Punic Spain to Persian Anatolia, the collection demonstrates both the breadth of the current field and a surprising number of synergies.

Readership

This volume is of interest to anyone interested in warfare in the Ancient Mediterranean, including institutes, academic libraries, public libraries, specialists, post-graduate students, undergraduate students, practitioners, and educated laymen.

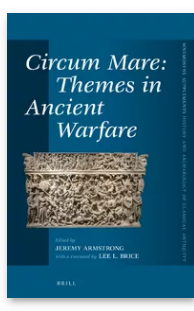

Pages: $\mathrm{x}, 322 \mathrm{pp}$.

Language:

English

Subjects:

Ancient History,

Classical

Studies, History

of Warfare,

History, History,

Ancient Near

East and Egypt

Publisher: Brill

Series:

Mnemosyne, Supplements,

Volume: 388

Mnemosyne,

Supplements,

History and

Archaeology of

Classical

Antiquity,

Volume: 388

E-Book (PDF)

Released online:

10 Jun 2016

ISBN: $978-90-$

04-28485-2

List price

USD $\$ 201.00$

Hardback

Publication date:

14Jul 2016 
ISBN: 978-90-

04-28484-5

List price

USD $\$ 201.00$

Order information: Order online at brill.com +44330 333 0049 | customerservices@brill.com Submission information: brill.com/authors

Titles published by Brill | Fink, Brill | mentis or Brill | Schöningh: +49(o)71 5413279216 | brill@brocom.de 